\title{
Use of Chaya (Cnidoscolous chayamansa) Leaves for Nutritional Compounds Production for Human Consumption
}

\author{
Milena María Ramírez Rodrigues ${ }^{1}$, Jorge Carlos Metri Ojeda ${ }^{1}$, Mariana González Díaz ${ }^{2}$, Diana Karina \\ Baigts Allende ${ }^{1^{*}}$ \\ ${ }^{1}$ Departamento de Ingeniería Química, Alimentos y Ambiental. Universidad de Las Américas Puebla, Ex \\ Hacienda Sta. Catarina Mártir, San Andrés Cholula, Puebla, 72810, México. \\ ${ }^{2}$ Unidad de Posgrado e Investigación, Universidad Latino, km 0.1 carretera Mérida-Cholul, Mérida, Yucatán, \\ 97305, México.
}

*Corresponding author: Diana Karina Baigts Allende, email: diana.baigts@udlap.mx

Received August 26 ${ }^{\text {th }}, 2020$; Accepted November 19 ${ }^{\text {th }}, 2020$.

DOI: http://dx.doi.org/10.29356/jmcs.v65i1.1433

\begin{abstract}
Chaya (Cnidoscolus chayamansa) is an edible leafy vegetable consumed in the southeast region of México and Central America; it is mainly appreciated for its protein content and bioactive compounds, such as polyphenols. In this work, chaya leaves were nutritionally characterized and used for the production of protein concentrates. The nutritional quality (amino acids, protein efficiency, and bioavailability) and structure by SDSPAGE, Fourier Transform Infrared Spectroscopy (FTIR), and Differential Scanning Calorimetry (DSC) of protein were analyzed. Additionally, the amount of some polyphenolic compounds were identified by LCMS/MS. Electrophoretic bands from RuBisCO protein subunits at $10 \mathrm{kDa}$ and $50 \mathrm{kDa}$ were observed. FTIR identified the typical protein footprint of secondary structure and DSC measurements showed a denaturation temperature $\sim 57^{\circ} \mathrm{C}$. Protein concentrates with a purity of $63.52 \pm 0.69 \%$ showed higher bioavailability than the control diet, and the essential amino acids met the FAO requirements without limiting amino acids. From the total polyphenol content, $14.8 \%$ corresponded to anthocyanidins, $61.0 \%$ hydroxycinnamic acids, $6.9 \%$ hydroxybenzoic acids, and $17.2 \%$ flavonols. Chaya leaves are a potential low-cost underutilized alternative source for the production of nutritional compounds for functional food product development for human nutrition. Keywords: Cnidoscolus chayamansa; plant protein; RuBisCO; polyphenols; human nutrition.
\end{abstract}

Resumen. La chaya (Cnidoscolus chayamansa), es una hoja comestible que se consume en las regiones del sureste de México y Centroamérica, es apreciada principalmente por su contenido de proteínas y compuestos bioactivos, tales como los polifenoles. En este trabajo, las hojas de chaya fueron caracterizadas nutricionalmente y utilizadas para la producción de concentrados proteicos. Se estudió la calidad nutrimental de la proteína (aminoácidos, eficiencia proteica y biodisponibilidad) y algunas características estructurales mediante técnicas analíticas como SDS-gel electroforesis, espectroscopía de infrarrojo por la transformada de Fourier (FTIR) y calorimetría diferencial de barrido (DSC). Asimismo, se determinó la cantidad total de polifenoles y se identificó el perfil de polifenoles mediante LC-MS/MS. Se observaron las bandas electroforéticas correspondientes a las subunidades de la proteína RuBisCO a $10 \mathrm{kDa}$ y $50 \mathrm{kDa}$. En el FTIR se identificó el espectro típico de la estructura secundaria de la proteína y DSC mostró una temperatura de desnaturalización $\sim 57{ }^{\circ} \mathrm{C}$. Los concentrados de proteína con pureza $\sim 63.52 \pm 0.69 \%$ mostraron mayor biodisponibilidad que el control y la cantidad de aminoácidos esenciales cumplieron con los requerimientos de la FAO sin aminoácidos limitantes. Del total del contenido de polifenoles, $14.8 \%$ correspondieron a las antocianidinas, $61.0 \%$ a ácidos hidroxicinámicos, $6.9 \%$ a ácidos hidroxibenzoicos y $17.2 \%$ a flavonoles. Las hojas de chaya pueden ser una fuente potencial alternativa para la producción de compuestos nutrimentales para el desarrollo de productos alimentarios funcionales para la nutrición humana.

Palabras clave: Cnidoscolus chayamansa; proteína vegetal; RuBisCO; polifenoles; nutrición humana. 


\section{Introduction}

The demand for food production, mainly due to the increasing world population, drives food science and technology to find more sustainable food sources. During the last years, research on native and underutilized crops as nutritional compounds for human nutrition has increased. One of the main challenges for assuring food security includes producing highly available food without compromising its nutritional value. It is well known that animal-derived ingredients are high in cost and less sustainable than plants, especially protein-rich products. In low-income regions of developing countries, malnutrition and hunger are prevalent, despite its biodiversity. Recently, plant-based proteins have been studied for partial or total substitution of animal proteins from both nutritional and techno-functional point of view. [1] The use of green leaves for leaf protein concentrates (LPC) has been suggested, not only because this protein is one of the most plentiful on earth but also because of its high biological value. Currently, LPCs are produced for animal feed, commonly manufactured from byproducts from alfalfa, beet-root, and tobacco leaves. Some green proteins from moringa leaves are being commercialized for human consumption due to its nutritional value. [1,2] RuBisCO enzyme (Ribulose 1,5Bisphosphate Carboxylase/Oxygenase) is one of the main proteins in leaves and has demonstrated to be a high biological value protein for its content profile of essential amino acids. [3]

Food proteins are critical because they are responsible for different physiological processes such as muscle and tissue development, hormone production, immune system improvement, among others. In childhood, stunting is the most common manifestation of protein malnutrition. Low intake of essential amino acids is associated with limited neurological and physical development and is highly frequent in children under five years old in developing countries. On the other hand, in the elderly, proper protein intake is critical due to the depletion of muscle tissue, which leads to a higher risk of injuries and lowers life quality. $[4,5]$ In the structure of food, proteins play an important role because of their functionality, such as solubility, emulsifying, foaming, and gelling properties, which are necessary to achieve unique characteristics in food products. Both functionality and nutritional value can be affected by protein structure loss. [6]

Chaya (Cnidoscolous chayamansa), also known as spinach three, is a common leafy vegetable domesticated in pre-Columbian times; this crop has been used mainly for food and medicine purposes by Mayan civilization and other Mesoamerican cultures. Its usage in southeastern México and Central America for the preparation of food has been documented, especially in Yucatán, Chiapas, Belize, and Guatemala, where chaya has been considered part of the daily diet. Among all regions where chaya is consumed, Yucatán has several dishes and beverages, for instance, Brazos de la Reina (chaya leaves mixed with corn dough and served with tomatoes and squash seeds), Dzotobulchay (chaya leaves mixed with nixtamalized corn dough), Pibxcatic (peppers stuffed with chaya leaves) and Chayagra (pineapple juice with lemon and chaya leaves). [7] Chaya leaves are appreciated for their nutritional properties, especially their protein content and bioactive compounds, mainly polyphenols. Chaya polyphenols have a growing interest due to their antioxidant capacity and their potential to prevent diseases due to bioactivities such as hepatoprotective, anti-inflammatory, and biological activity against cancer and liver problems. [8-12] Although this crop has been studied for its biological activity and toxicity, chaya LPC has been used mainly for animal feeding. $[13,14]$ This work aimed to widen knowledge acquirement in chaya leaves by exploring the potential applicability of protein and polyphenol nutritional compounds to encourage the development of functional food products.

\section{Experimental}

Chaya leaves were acquired from a local market in Mérida city located in Yucatán state, México. Reagents including $\mathrm{HCl}, \mathrm{NaOH}$, sodium borate, diethyl-ethoxymethylenmalonate, Folin-Ciocalteau, $\mathrm{Na}_{2} \mathrm{Co}_{3}$, gallic acid, polyphenol standards (chlorogenic acid, cyanidin chloride, epicatechin, $p$-coumaric acid, and vanillic acid), digestive enzymes and bile extracts were purchased from Sigma Aldrich (Missouri, USA). 


\section{Leaf protein concentrates (LPC)}

Leaves were ground and macerated in an alkaline solution at $\mathrm{pH} 13$. The solution was separated by filtration and acidified using $\mathrm{HCl}(0.1 \mathrm{~N})$ until reaching a $\mathrm{pH}$ of 3.5. Once the protein was precipitated, it was centrifuged at $6000 \mathrm{rpm}$ and $4{ }^{\circ} \mathrm{C}$ for $20 \mathrm{~min}$, neutralized, and dried in a vacuum oven at $60{ }^{\circ} \mathrm{C}$ until moisture content was below $15 \%$. [15]

\section{Proximate analysis}

Proximate analyses of chaya leaves and LPC were determined according to the AOAC official methods [16] for dry matter (925.09), protein (954.01), ash content (923.93), crude fat (920.39), and crude fiber (962.09). Carbohydrates were calculated by difference $[100-($ moisture + protein + ash content + crude fat + crude fiber $)]$. [17]

\section{Nutritional quality Amino acid composition}

The amino acid composition was determined, according to Alaiz et al. [18] method. An amount of 15 mg of LPC was mixed with $1.5 \mathrm{~mL}$ of $\mathrm{HCl} 6 \mathrm{~N}$ at $110{ }^{\circ} \mathrm{C}$ for 24 hours. After this, $\mathrm{HCl}$ was evaporated and the protein was mixed with BoNa $1 \mathrm{M}$ to achieve a volume of $1.5 \mathrm{~mL}$. An excess of diethylethoxymethylenmalonate was added to the sample. It was analyzed in an HPLC equipment (Agilent 1100 series, Agilent Technologies Inc, California, USA) with a $300 \mathrm{~mm}$ x $3.9 \mathrm{~mm}$ Nova Pack C 18, $4 \mathrm{~mm}$ reversed-phase column (Waters, Massachusetts, USA) at $0.9 \mathrm{~mL} / \mathrm{min}$ for 40 minutes at $18{ }^{\circ} \mathrm{C}$.

\section{Amino acid score (AAS)}

Limiting amino acids was used to determine the amino acid score. One $\mathrm{mg}$ of amino acid in a protein is compared with one amino acid per gram of protein of FAO recommendations (Eq. 1). Also, the proportion of essential amino acids (EAA) related to total amino acid (TAA) was calculated with Eq. (2) and expressed as \% $\mathrm{E} / \mathrm{T}$. [19]

$$
\begin{aligned}
& \% A A S=\frac{m g \text { amino acid per } g \text { of protein }}{\text { recommendation of } m g \text { amino acid per } g \text { of protein }} \times 100 \\
& \% \frac{E}{T}=\frac{E A A}{T A A} \times 100
\end{aligned}
$$

\section{Protein efficiency ratio (PER)}

The protein efficiency ratio (PER) was used for the prediction of protein quality, it was calculated by Eqs. (3)-(5). [20]

$$
\begin{aligned}
& \text { PER } 1=-0.684+0.456(\text { Leu })-0.047(\text { Pro }) \\
& \text { PER2 }=-0.468+0.454(\text { Leu })-0.105(\text { Tyr }) \\
& \text { PER3 }=-1.816+0.435(\text { Met })+0.78(\text { Leu })+0.211(\text { Hys })-0.944(\text { Tyr })
\end{aligned}
$$

\section{Protein bioavailability}

In vitro digestion of a control-diet constituted of protein, carbohydrates, and lipids using meat and casein peptone, corn oil, flour, and sugar ( 1000 kcal), and a supplemented diet with chaya LPC was carried 
out. In the stomach, the samples were acidified to $\mathrm{pH} 2$ and kept in continuous stirring. Next, the pepsin enzyme (porcine stomach) was added. Afterward, before adding pancreatic enzymes and bile salts, the $\mathrm{pH}$ was adjusted to $\sim 5.5-6$. In the end, the final $\mathrm{pH}$ was re-adjusted $(\mathrm{pH}=\sim 7)$, and the protein content was determined by the AOAC method 954.01. [16]

\section{Protein structure SDS-PAGE gel electrophoresis}

The molecular weight of LPC was determined using SDS gel electrophoresis in reducing conditions. A solution containing $0.04 \mathrm{~g} / \mathrm{mL}$ of true protein (based on LPC protein content determined by AOAC method 954.01) was analyzed according to Laemmli protocol. [21] The sample was mixed with buffer (5\% glycerol, $20 \%$ SDS, $0.1 \%$ bromophenol blue, and $2 \%$ mercaptoethanol) in a ratio of 1:1. The electrophoretic test was carried out using a Bio-rad (Bio-rad, California, USA) mini- Protean N Tetra Cell 4-Gel System at $90 \mathrm{~V}$ for $100 \mathrm{~min}$ [22] and a molecular Dual Standard 250 - $10 \mathrm{kDa}$ (Bio-rad, California, USA) as a marker. The gel was stained for $45 \mathrm{~min}$ with a solution containing ethanol, water, and acetic acid in proportions of 70:20:5 and 0.1\% Coomassie Blue. Afterward, the gel was discolored with ethanol, water, and acetic acid (70:20:5) solution until no further color was released.

\section{Fourier-Transform Infrared Spectroscopy (FTIR)}

The FTIR measurements of LPC were recorded at $400-4000 \mathrm{~cm}^{-1}$ wavelength with an Agilent Cary 630 spectrophotometer coupled with ATR ZNSe. The absorbance spectrums were analyzed using Microlab PC software (Agilent Technologies Inc., California, USA). [23]

\section{Differential Scanning Calorimetry (DSC)}

For DSC analysis, an amount of $10 \mathrm{mg}$ of protein quantified by the AOAC method 954.01 with $30 \%$ of water (w/v) was placed in hermetically sealed aluminum plate pans. Heat scan was from $20{ }^{\circ} \mathrm{C}$ to $90{ }^{\circ} \mathrm{C}$ at $10^{\circ} \mathrm{C} /$ min using a Q200 calorimeter (TA Instruments, Delaware, USA). Universal Analysis 2000 software (TA Instruments, Delaware, USA) was used to calculate enthalpies. [24]

\section{Total polyphenols content and polyphenolic profile determination}

Total phenolics content in three different extracts: chaya leaves, protein precipitation remnant, and pellet from protein extraction (leaves after the whole protein extraction process) were quantified using the Folin Ciocalteau method. Polyphenolic compounds were extracted twice from macerated leaves using methanolwater (80:20) in a ratio of 1:4 (leaves: solvent). Leaves were kept under constant stirring at room temperature for $2 \mathrm{~h}$ and centrifuged for $15 \mathrm{~min}$ at $4500 \mathrm{rpm}$ and $4{ }^{\circ} \mathrm{C}$; the polyphenol extracts were stored at $-20{ }^{\circ} \mathrm{C}$ until further use. Folin-Ciocalteau reagent $(250 \mu \mathrm{L}, 1 \mathrm{~N})$ was added to $20 \mu \mathrm{L}$ of polyphenol extract and let rest for 3 min in darkness. Afterward, $1250 \mu \mathrm{L}$ of $\mathrm{Na}_{2} \mathrm{CO}_{3} 20 \%$ (w/v) and $480 \mu \mathrm{L}$ of distilled water were added and left in darkness for two h. The final absorbance was measured at $760 \mathrm{~nm}$ using a UV-Vis spectrophotometer (Genesys 10S, Thermo Scientific, Massachusetts, USA). A gallic acid calibration curve $(0.01-0.5 \mathrm{mg} / \mathrm{mL})$ was used as standard.

For polyphenolic profile determination, the samples were filtered through a $0.2 \mu \mathrm{m}$ nylon syringe filter before chromatographic analysis. A Waters (Massachusetts, USA) LC-MS/MS (liquid chromatography-mass spectrometer) was used for the identification and quantification of polyphenols. An Acquity UPLC BEH C18 $(2.1 \times 100 \mathrm{~mm}, 1.7 \mu \mathrm{m})$ column was used for compounds separation. Mobile phases were $0.1 \%(\mathrm{v} / \mathrm{v})$ formic acid in water (A) and $0.1 \%(\mathrm{v} / \mathrm{v})$ formic acid in methanol (B). The column was maintained at $40{ }^{\circ} \mathrm{C}$. A flow rate of $0.45 \mathrm{~mL} / \mathrm{min}$ and an injection volume of $5 \mu \mathrm{L}$ were used. Total run time of 14.5 min with $99 \% \mathrm{~A}$ at 0.5 min, $20 \% \mathrm{~A}$ at $13.5 \mathrm{~min}$, and $99 \% \mathrm{~A}$ at $14 \mathrm{~min}$.

Quattro Premier XE triple quadrupole mass spectrometer fitted with electrospray ionization (ESI) was used in positive mode for cyanidin and epicatechin. In contrast, the negative mode was used for chlorogenic acid, $\rho$-coumaric acid, rutin, and vanillic acid. Mass spectrometer optimization was conducted by direct infusion of $50 \mathrm{mg} / \mathrm{L}$ stock standard solutions to select the ionization mode and precursor and ions production. The calibration curves of the above-mentioned polyphenols standards were used for quantification. 


\section{Results and discussion}

\section{Proximate analysis}

The proximal composition of chaya leaves and chaya LPC is shown in Table 1. Chaya leaves showed higher protein content $(32.09 \pm 0.48 \%)$ compared with chaya (Cnidoscolus aconitifolius) leaves at different ages of regrowth ( 27\%), [25] and other leafy vegetables like lettuce, spinach, and moringa (19\%, $23 \%$, and $18 \%$ respectively). [26, 27] Ash content, which represents mineral content, was slightly lower than Cnidoscolus aconitifolius $(\sim 10 \%)$. Both ash and fiber content were similar to the reported values for Eruca vesicaria leaves (9.3\% of ash content and $6 \%$ of fiber); however, the chemical composition is different in other leafy vegetables, for example, amaranth (Amaranthus cruentus) and spinach (Spinacia oleracea) have approximately $16-18 \%$ of ash content and $14-16 \%$ of fiber, considerably higher than the results found in chaya leaves. [28, 29, 30] It is well known that several factors can influence the composition of crops, such as climate, age of growth, and harvesting conditions, among others.

Table 1. Proximate analysis of chaya leaves and chaya leaf protein concentrate (LPC).

\begin{tabular}{|l|c|c|}
\hline & Chaya leaves & Chaya LPC \\
\hline Moisture (\%) & $81.96 \pm 0.51$ & $9.41 \pm 0.36$ \\
\hline Protein (\%) & $32.09 \pm 0.48$ & $63.52 \pm 0.69$ \\
\hline Ash (\%) & $7.88 \pm 0.25$ & ND \\
\hline Fiber (\%) & $9.33 \pm 0.47$ & ND \\
\hline Fat (\%) & $5.20 \pm 0.14$ & ND \\
\hline Carbohydrates (\%) & $43.33 \pm 1.26$ & ND \\
\hline
\end{tabular}

* Dry basis. ND: Not determined.

In the case of LPC, the content of protein compared to other LPCs obtained from leaves of different crops was much higher ( 62\%) in comparison to LPCs from Diplazium esculentum, Albizia lebbeck, and Amaranthus hybridus ( $34 \%, 37 \%$, and $39 \%$ respectively). [30, 32, 33] However, alfalfa (Medicago sativa) and moringa (Moringa oleifera) LPCs showed similar content of protein $(60-70 \%)$ than in our study. [34, 35]

\section{Nutritional quality}

The amino acid profile, ET, and PER values for chaya leaves, and LPC are shown in Table 2. The results for leaves were similar to previously reported values for $C$. chayamansa. [36] Chaya LPC showed a lower amount of essential amino acids, such as Lys, Leu, and Ile. Still, a higher quantity of Trp and Val in comparison to LPCs produced with Amaranthus hybridus leaves [31], Amaranthus spp, eggplant [37], Gliricidia sepium, Leucaena leucocephala [38], and Medicago sativa L. [34]; however, no limiting amino acids were found. The LPC meets the required amounts for children above five years old, adolescents, and adults recommended by FAO [19] (Table 3). According to the PER value, Chaya leaves can be considered high-quality because the value was higher than 2 (2.87); however, in LPC, these values slightly decreased (2.54). [39] It has been reported that the extraction process of protein could negatively affect its quality due to some amino acids may be partially degraded or destroyed by thermal or acid/alkali processing. [40] On the other hand, in vitro digestibility studies showed that chaya LPC was more bioavailable at both the stomach $(1.35 \mathrm{~g} / 100 \mathrm{ml})$ and small intestine $(0.94 \mathrm{~g} / 100 \mathrm{~mL})$ in in vitro conditions compared to the protein present in the control diet (1.08 and $0.78 \mathrm{~g} / 100 \mathrm{~mL}$, respectively). These results suggest that chaya LPC could be considered as a good alternative for animal protein substitution in human consumption. There is no information related to the digestibility of leaf proteins in humans. Nevertheless, studies performed on meals using protein from different sources showed higher digestibility for spirulina meal than pork, soybean, and chickpea meals. [41] 
Table 2. Amino acid composition of chaya leaves and chaya leaf protein concentrate (LPC) (mg/g protein) $\mathrm{E} / \mathrm{T}^{*}(\%)$ and $\mathrm{PER}^{+}$.

\begin{tabular}{|c|c|c|}
\hline & Chaya leaves & Chaya LPC \\
\hline Asp & $63.62 \pm 0.39$ & $65.10 \pm 0.35$ \\
\hline Glu & $129.60 \pm 0.64$ & $100.40 \pm 0.24$ \\
\hline Ser & $49.41 \pm 0.21$ & $29.00 \pm 0.14$ \\
\hline Hys & $21.35 \pm 0.44$ & $21.60 \pm 0.22$ \\
\hline Gly & $53.44 \pm 0.27$ & $39.10 \pm 0.06$ \\
\hline Thr* & $49.47 \pm 0.11$ & $32.40 \pm 0.06$ \\
\hline Arg & $120.92 \pm 0.51$ & $95.30 \pm 0.26$ \\
\hline Ala & $29.32 \pm 0.00$ & $26.50 \pm 0.08$ \\
\hline Pro & $124.31 \pm 0.58$ & $228.70 \pm 1.34$ \\
\hline Tyr & $36.54 \pm 0.07$ & $42.90 \pm 0.09$ \\
\hline Val* & $63.47 \pm 0.07$ & $57.00 \pm 0.02$ \\
\hline Met* & $10.44 \pm 0.11$ & $16.50 \pm 0.06$ \\
\hline Cys & $9.51 \pm 0.15$ & $10.70 \pm 0.00$ \\
\hline Ile* & $46.08 \pm 0.13$ & $40.80 \pm 0.08$ \\
\hline Leu* $^{*}$ & $82.84 \pm 0.20$ & $76.20 \pm 0.24$ \\
\hline Phe* & $51.51 \pm 0.07$ & $53.30 \pm 0.16$ \\
\hline Lys* & $46.32 \pm 0.08$ & $49.10 \pm 0.21$ \\
\hline Trp* & $11.84 \pm 0.04$ & $15.60 \pm 0.00$ \\
\hline EAA & 351.45 & 325.67 \\
\hline $\mathrm{E} / \mathrm{T}$ & $33.47 \%$ & $32.47 \%$ \\
\hline $\mathrm{PER}_{1}$ & 2.47 & 1.71 \\
\hline $\mathrm{PER}_{2}$ & 2.87 & 2.54 \\
\hline $\mathrm{PER}_{3}$ & 2.07 & 1.28 \\
\hline
\end{tabular}

$* \mathrm{E} / \mathrm{T}=$ essential $/$ total amino acids. ${ }^{+} \mathrm{PER}=$ protein efficiency ratio.

Table 3. Amino acid score value in chaya leaves and chaya leaf protein concentrate (LPC) compared with FAO standard guideline consumption [19].

\begin{tabular}{|c|c|c|c|c|c|c|c|c|c|}
\hline \multicolumn{8}{|c|}{ Amino acid recommendations (mg/g protein) and amino acid score value (AAS) (\%). } \\
\hline & Ile & Leu & Lys & His & AAA $^{*}$ & SAA $^{+}$ & Trh & Trp & Val \\
\hline FAO standard & 30.00 & 61.00 & 48.00 & 16.00 & 41.00 & 23.00 & 25.00 & 6.60 & 40.00 \\
\hline Chaya leaves & 46.08 & 82.84 & 46.32 & 21.35 & 99.75 & 19.95 & 49.47 & 11.84 & 63.47 \\
\hline AAS (leaves) & 100.00 & 100.00 & 96.50 & 100.00 & 100.00 & 86.70 & 100.00 & 100.00 & 100.00 \\
\hline Chaya LPC & 40.80 & 76.20 & 49.10 & 21.60 & 111.80 & 27.20 & 32.40 & 15.60 & 57.00 \\
\hline $\begin{array}{c}\text { AAS (Chaya } \\
\text { LPC) }\end{array}$ & 100.00 & 100.00 & 100.00 & 100.00 & 100.00 & 100.00 & 100.00 & 100.00 & 100.00 \\
\hline
\end{tabular}

*AAA: Aromatic amino acids. ${ }^{+}$SAA: Sulphur amino acids.

\section{Protein structure \\ SDS-PAGE gel electrophoresis}

Green leaves are constituted primarily by two sorts of protein fractions, the proteins complexed with pigments (chlorophyll) present in the thylakoid membrane (known as green protein) and the soluble proteins (white protein). This white protein is an enzyme known by its short name RuBisCO (Ribulose 1,5-Bisphosphate Carboxylase/Oxygenase), this soluble protein and some chloroplastic proteins were observed in SDS-page gel electrophoresis. The subunit bands (small and large) of the soluble protein (RuBisCO) were detected at molecular weights of $50 \mathrm{kDa}$ and $10 \mathrm{kDa}$ (Fig. 1). Identical bands have been reported in alfalfa and spinach LPCs. $[42,43]$ 


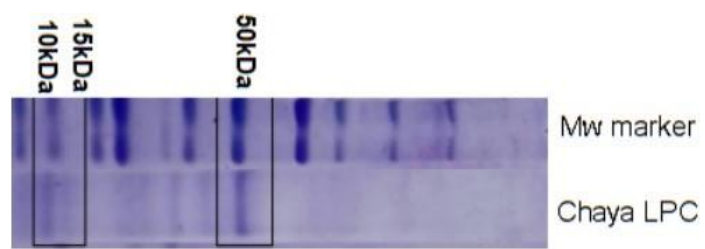

Fig. 1. Gel electrophoresis of chaya leaf protein concentrate (LPC) for protein detection.

\section{Thermal stability and secondary protein structure (DSC and FTIR)}

The thermal stability and protein footprint of chaya LPC are shown in Fig. 2. The enthalpic peaks during the heating ramp of LPC evinced the presence of protein (Fig. 2(A)). The denaturation temperature of chaya LPC was $\sim 57{ }^{\circ} \mathrm{C}$. These concentrates showed slightly lower thermal stability than RuBisCO proteins $\left(63{ }^{\circ} \mathrm{C}-75^{\circ} \mathrm{C}\right)$ obtained from different vegetable sources such as alfalfa, spinach, and Diplazium esculentum. $[24,33,43]$

In the FTIR spectra, the typical protein footprint represented mainly by the Amide A $\left(3300 \mathrm{~cm}^{-1}\right)$, Amide I $\left(1600-1690 \mathrm{~cm}^{-1}\right)$, and Amide II $\left(1480-1575 \mathrm{~cm}^{-1}\right)$ regions was observed (Fig. 2(B)), Amide I band is related to $\mathrm{C}=\mathrm{O}$ stretching in the peptide bonds. This absorbance peak is often used to predict the content of secondary structural elements such as $\alpha$-helixes, $\beta$-sheets, and random coils. On the other side, Amide A indicates the stretching of $\mathrm{NH}$ bonds, and Amide II represents $\mathrm{CN}$ stretching and $\mathrm{NH}$ bending of the protein molecule. Another region of interest is between $2800-2900 \mathrm{~cm}^{-1}$, which measures the $\mathrm{CH}_{2}$ and $\mathrm{CH}_{3}$ asymmetric stretching of fatty acids; the low absorbance in the LPC might indicate a small proportion of lipids in the samples. Moreover, the presence of peaks around $900-1200 \mathrm{~cm}^{-1}$ is commonly related to the stretching of hydroxyl groups of carbohydrate moieties; therefore, some soluble carbohydrates may be present in the LPC. [44-47]
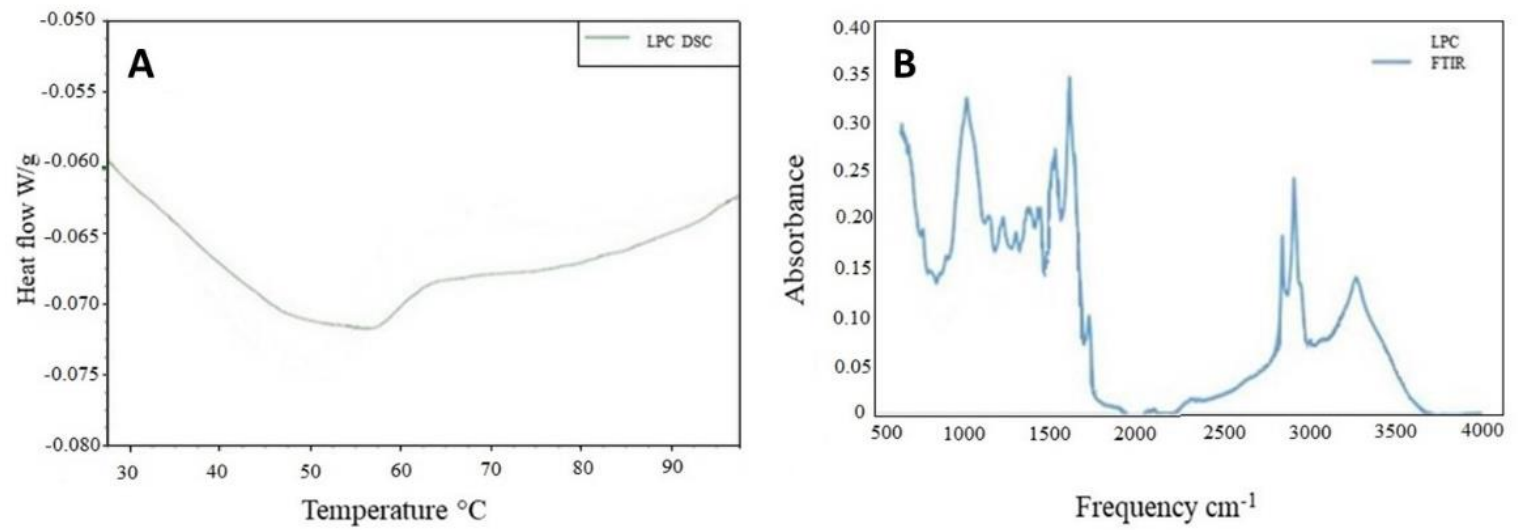

Fig. 2. (A) Differential Scanning Calorimetry (LPC DSC) and (B) Fourier Transform Infrared Spectroscopy (LPC FTIR) in chaya leaf protein concentrate (LPC).

\section{Polyphenol content}

The content of polyphenols in chaya leaves and the remnant solution from protein precipitation was similar (3.0 and $3.5 \mathrm{mg} \mathrm{GAE} / \mathrm{g}$, respectively) and significantly decreased in the pellet from protein extraction $(0.8 \mathrm{mg} \mathrm{GAE} / \mathrm{g})$. The values in the leaves and remnant were according to a previous study of $C$. chayamansa, Ramos-Gomez et al. [48], who found a total polyphenol content of $3.35 \mathrm{mg} \mathrm{GAE} / \mathrm{g}$, respectively. Nevertheless, 
other studies with the same crop $(C$. chayamansa) have shown higher polyphenols content $(6.34-71.3 \mathrm{mg}$ $\mathrm{GAE} / \mathrm{g}$ ), however, the extraction conditions were different to this study (distilled water at $90{ }^{\circ} \mathrm{C}$ ). It is well known that high temperatures increase the extraction rate of different compounds such as polyphenols. $[9,49,50]$ On the other side, the highest concentration (71.3 mg GAE/g) found by Loarca-Piña et al. [9] was obtained using an extensive extraction of 5 days at room temperature with hexane-acetone, and a second extraction with methanol was also applied.The differences observed in the total polyphenols could be due to different reasons such as the type of solvent used for extraction (acetone, ethanol, methanol, or water), total extraction time, harvesting conditions, crop age state [9,49], and the type of standard used for the calibration curve. The fact that similar amounts of polyphenols were present after protein extraction could indicate that protein-polyphenol conjugates were not formed during protein precipitation. From an added value and nutritional point of view, chaya leaves could be used as a source of these two nutritional compounds without compromising protein quality caused often by non-proteinaceous elements which can cause off-flavors and a decrease in digestibility.

\section{Polyphenol profile}

The identified and quantified polyphenols in chaya leaves are presented in Table 4. The obtained profile consisted of $14.8 \%$ anthocyanidins (cyanidin), $61.0 \%$ hydroxycinnamic acids (3-chlorogenic acid and $p$-coumaric acid), $6.9 \%$ hydroxybenzoic acids (vanillic acid), and $17.2 \%$ flavonols (epicatechin and rutin). All these polyphenols have been previously reported in chaya. [48,50] A quercetin concentration of 0.040-0.045 $\mathrm{mg} / \mathrm{g}$ was reported in C. chayamansa raw leaves [50], which is similar to the rutin (quercetin-3-O-rutinoside) content found in this work $(0.043 \mathrm{mg} / \mathrm{g})$. Chaya leaves extracts have been studied for their potential health benefits, including antimutagenic, antidiabetic, and antioxidant activities $[9,48]$ showing promising nutritional applications for this plant extract.

Table 4. Identification and quantification of polyphenolic compounds in chaya leaves

\begin{tabular}{|c|c|c|c|c|c|}
\hline Compound & $\begin{array}{c}\text { Ionization } \\
\text { Mode }\end{array}$ & $\begin{array}{c}\text { Parent ion } \\
(\mathbf{m} / \mathbf{z})\end{array}$ & $\begin{array}{c}\text { Product } \\
\text { ion } \mathbf{( m / z )}\end{array}$ & $\begin{array}{c}\text { Cone } \\
\text { voltage } \\
(\mathbf{V})\end{array}$ & $\begin{array}{c}\text { Concentration } \\
(\mathbf{m g} / \mathbf{g}) *\end{array}$ \\
\hline Cyanidin & + & 287.00 & 137.11 & 50 & $0.115 \pm 0.01$ \\
\hline Epicatechin & + & 291.00 & 138.98 & 55 & $0.431 \pm 0.01$ \\
\hline 3-Chlorogenic acid & - & 353.00 & 178.95 & 30 & $0.092 \pm 0.00$ \\
\hline p-Coumaric acid & - & 163.00 & 119.00 & 28 & $0.044 \pm 0.00$ \\
\hline Vanillic acid & - & 167.00 & 151.99 & 40 & $0.052 \pm 0.00$ \\
\hline Rutin & - & 609.00 & 301.10 & 70 & $0.043 \pm 0.00$ \\
\hline
\end{tabular}

* Results expressed in $\mathrm{mg} / \mathrm{g}$ of chaya leaves Data are presented as mean \pm SD $(n=3)$.

\section{Conclusion}

Chaya leaves can be valorized for a sequential production of ingredients for developing high nutritional quality food products for human consumption. The protein concentrates could be used for partial replacement of animal-protein due to its amino acid composition (no limiting amino acids) and digestibility being a more affordable source of protein for low incomes population regions.

\section{Acknowledgments}

The authors thank CONACyT for the funding of the FOINS 24639 project (analytical determinations), CIATEJ southeast unit for the infrastructure and equipment, and Dr. Avila, Ruiz and Chel for the amino acid bioavailability analyses. 


\section{References}

1. Day, L. Trends Food Sci. Technol. 2013, 32, 25-42. DOI: https://doi.org/10.1016/j.tifs.2013.05.005

2. Boland, M. J.; Rae, A. N.; Vereijken, J. M.; Meuwissen, M. P.; Fischer, A. R.; van Boekel, M. A.; Rutherfurd, S. M.; Gruppen, H.; Moughan, P. J.; Hendriks, W. H. Trends Food Sci. Technol. 2013, 29, 62-73. DOI: https://doi.org/10.1016/j.tifs.2012.07.002

3. Edelman, M.; Colt, M. Frontiers in Chemistry. 2016, 4, 1-5. DOI: https://doi.org/10.3389/fchem.2016.00032

4. Kim, J. S.; Wilson, J. M.; Lee, S. R. J. Nutr. Biochem. 2010, 21, 1-13. DOI: https://doi.org/10.1016/i.jnutbio.2009.06.014

5. Semba, R. D.; Shardell, M.; Ashour, F. A. S.; Moaddel, R.; Trehan, I.; Maleta, K. M.; Ordiz, M. I.; Kraemer, K.; Khadeer, M. A.; Ferrucci, L.; Manary, M. J. EBioMedicine. 2016, 6, 246-252. DOI: https://doi.org/10.1016/j.ebiom.2016.02.030

6. Haque, M. A.; Timilsena, Y. P.; Adhikari, B., in: Reference Module in Food Science, Elsevier, 2016. DOI: https://doi.org/10.1016/B978-0-08-100596-5.03057-2.

7. Ross-Ibarra, J.; Molina-Cruz, A. Economic Botany. 2002, 56, 350-365

8. García-Rodríguez, R V.; Gutiérrez-Rebolledo, G. A.; Méndez-Bolaina, E.; Sánchez-Medina, A.; Maldonado-Saavedra, O.; Domínguez-Ortiz, M. Á.; Vázquez-Hernández, M.; Muñoz-Muñiz, O. D.; Cruz-Sánchez, J. S. Journal of Ethnopharmacology. 2014, 151, 937-943. DOI: https://doi.org/10.1016/i.jep.2013.12.004

9. Loarca-Piña, G.; Mendoza, S.; Ramos-Gómez, M.; Reynoso, R. Journal of Food Science. 2010, 75 , H68-H72. DOI: https://doi.org/10.1111/j.1750-3841.2009.01505.X

10. Pérez-González, M. Z.; Gutiérrez-Rebolledo, G. A.; Yépez-Mulia, L.; Rojas-Tomé, I. S.; LunaHerrera, J.; Jiménez-Arellanes, M. A. Biomedicine \& Pharmacotherapy. 2017, 89, 89-97. DOI: https://doi.org/10.1016/j.biopha.2017.02.021

11. Pérez-González, M. Z.; Macías-Rubalcava, M. L.; Hernández-Ortega, S.; Siordia-Reyes, A. G.; Jiménez-Arellanes, M. A. Biomedicine \& Pharmacotherapy. 2019, 117, 1-10. DOI: https://doi.org/10.1016/j.biopha.2019.109140.

12. Pérez-González, M. Z.; Siordia-Reyes, A. G.; Damián-Nava, P.; Hernández-Ortega, S.; MacíasRubalcava, M. L.; Jiménez-Arellanes, M. A. Evidence-Based Complementary and Alternative Medicine. 2018, 2018, 1-12. DOI: https://doi.org/10.1155/2018/3896517

13. Anil, K.; Alzahal, O.; Singh, K. K.; McBride, B. W. Indian Journal of Animal Sciences. 2010, 80, 1008-1010.

14. Aguilar-Ramírez, J.; Santos-Ricalde, R.; Pech-Martínez, V.; Montes-Pérez, R. Revista Biomédica. 2000, 11, 17-24. DOI: https://doi.org/10.32776/revbiomed.v11i1.215

15. Colas, D.; Doumeng, C.; Pontalier, P. Y.; Rigal, L. Food and Bioproducts Processing. 2013, 91, 175182. DOI: https://doi.org/10.1016/j.fbp.2013.01.002

16. Association of Official Analytical Chemists. Official Methods of Analysis. AOAC International, 16th Ed., Washington DC, 2005.

17. Olvera-Novoa, M. A.; Martinez Palacios, C. A.; Real de Leon, E. Nutrition of fish and crustaceans: a laboratory manual. Food and Agriculture Organization of The United Nations-FAO, Mexico City, 1994.

18. Alaiz, M.; Navarro, J. L.; Girón, J.; Vioque, E. J. Chromatog. A. 1992, 591, 181-186. DOI: https://doi.org/10.1016/0021-9673(92)80236-N

19. Food and Agriculture Organization of the United Nations. FAO Food and Nutrition Paper. 2011, 92 , $1-62$.

20. Alsmeyer, R. H.; Cunningham, A. E.; Happich, M. L. Food Technol. 1974, 28, 34-40.

21. Laemmli, U. K. Nature. 1970, 227, 680-685.

22. Khan, S. A.; Shinwari, Z. K.; Rabbani, M. A. Pak. J. Bota. 2013, 45, 871-876.

23. Zhao, X.; Chen, F.; Xue, W.; Lee, L. Food Hydrocolloids, 2008, 22, 568-575. DOI: https://doi.org/10.1016/j.foodhyd.2007.01.019 
24. Martín, A. H.; Nieuwland, M.; de Jong, G. A. H. J. Agric. Food Chem. 2014, 62, 10783-10791. DOI: https://doi.org/10.1021/jf502905g

25. Sarmiento-Franco, L.; Sandoval-Castro, C. A.; McNab, J. M.; Quijano-Cervera, R.; Reyes-Ramirez, R. R. J. Sci. Food Agric. 2003, 83, 609-612. DOI: https://doi.org/10.1002/jsfa.1372

26. Alain Mune Mune, M.; Nyobe, E. C.; Bakwo Bassogog, C.; Minka, S. R. Cogent Food Agric. 2016, 2 , 1-8. DOI: https://doi.org/10.1080/23311932.2016.1213618

27. Hanif, R.; Iqbal, Z.; Iqbal, M.; Hanif, S.; Rasheed, M. J. Agricultur. Biologic. Sci. 2006, 1, 18-22.

28. Bukhsh, E.; Salman, A. M.; Sheikh, S. A. Pak. J. Bot. 2007, 39, 1181-1187.

29. Pereira, C.; Dias, M. I.; Petropoulos, S. A.; Plexida, S.; Chrysargyris, A.; Tzortzakis, N.; Calhelha, R. C.; Ivanov, M.; Stojković, D.; Stojković, M.; Barros, L.; Ferreira, I. C. F. R. Molecules. 2019, 24, 1 28. DOI: https://doi.org/10.3390/molecules24244494

30. Traoré, K.; Parkouda, C.; Savadogo, A.; Ba/Hama, F.; Kamga, R.; Traoré, Y. Food Sci. Nut. 2017, 5, 1139-1144. DOI: 10.1002/fsn3.504

31. Adeyeye, E. I.; Omolayo, F.O. Agric. Biol. J. North Am. 2011, 2, 499-511. DOI: https://doi:10.5251/abjna.2011.2.3.499.511

32. Khan, L. H.; Varshney, V. K. J. Diet. Suppl. 2018, 15, 386-397. DOI: https://doi.org/10.1080/19390211.2017.1349232

33. Saha, J.; Deka, S. C. Int. J. Food Prop. 2017, 20, 1051-1061. DOI: https://doi.org/10.1080/10942912.2016.1199034

34. Hojilla-Evangelista, M. P.; Selling, G. W.; Hatfield, R.; Digman, M. J. Sci. Food Agric. 2017, 97, 882888. DOI: https://doi.org/10.1002/jsfa.7810

35. Rawdkuen, S. Food and Applied Bioscience Journal. 2020, 8, 43-47.

36. Ranhotra, G. S.; Gelroth, J. A.; Leinen, S. D.; Vinas, M. A.; Lorenz, K. J. J. Food Compos. Anal. 1999, 11, 298-304. DOI: https://doi.org/10.1006/jfca.1998.0590

37. Famuwagun, A. A.; Alashi, A. M.; Gbadamosi, S. O.; Taiwo, K. A.; Oyedele, D. J.; Adebooye, O. C.; Aluko, R. E. Int. J. Food Prop. 2020, 23, 955-970. DOI: https://doi.org/10.1080/10942912.2020.1772285

38. Agbede, J. O.; Aletor, V.A. Int. J. Food Sci. Technol. 2004, 39, 253-261. doi:10.1111/j.13652621.2004.00779.x

39. Zengin, G.; Aktumsek, A.; Guler, G. O.; Cakmak, Y. S.; Girón-Calle, J.; Alaiz, M.; Vioque, J. Food Chem. 2012, 135, 1360-1364. DOI: https://doi.org/10.1016/j.foodchem.2012.05.084

40. Rutherfurd, S. M.; Moughan, P. J. British J. Nut. 2012, 108, S298-S305. DOI: https://doi.org/10.1017/S0007114512002528

41. Montoya-Martínez, C.; Nolasco-Soria, H.; Vega-Villasante, F.; Carrillo-Farnés, O.; ÁlvarezGonzález, A.; Civera-Cerecedo, R. Latin Am. J. Aquatic Res. 2018, 46, 495-501. DOI: http://dx.doi.org/10.3856/vol46-issue3-fulltext-1.

42. Di Stefano, E.; Agyei, D.; Njoku, E. N.; Udenigwe, C. C. J. Am. Oil Chemists' Soc. 2018, 95, 10631074. DOI: https://doi.org/10.1002/aocs.12104

43. Lamsal, B. P.; Koegel, R. G.; Gunasekaran, S. LWT - Food Sci. Tech. 2007, 40, 1520-1526. DOI: https://doi.org/10.1016/j.lwt.2006.11.010

44. Andrade, J.; Pereira, C. G.; de Almeida Junior, J. C.; Viana, C. C. R.; de Oliveira Neves, L. N.; da Silva, P. H. F.; Valenzuela Bell, M. J.; dos Anjos, V. D. C. LWT. 2019, 99, 166-172. DOI: https://doi.org/10.1016/j.lwt.2018.09.079

45. Karthikeyan, S.; Vizhiselvi, K. Indian Journal of Pure and Applied Physics. 2017, 55, 525-531.

46. Kong, J.; Yu, S. Acta Biochimica et Biophysica Sinica. 2007, 39, 549-559. DOI: https://doi.org/10.1111/j.1745-7270.2007.00320.x

47. Sazonova, S.; Grube, M.; Shvirksts, K.; Galoburda, R.; Gramatina, I. Journal of Molecular Structure. 2019, 1186, 377-383. DOI: https://doi.org/10.1016/j.molstruc.2019.03.038

48. Ramos-Gomez, M.; Figueroa-Pérez, M. G.; Guzman-Maldonado, H.; Loarca-Piña, G.; Mendoza, S.; Quezada-Tristán, T.; Reynoso-Camacho, R. J. Food Biochem. 2017, 41, 1-9. DOI: https://doi.org/10.1111/jfbc.12281 
49. Valenzuela Soto, R.; Morales Rubio, M. E.; Verde Star, M. J.; Oranday Cárdenas, A.; Preciado-Rangel, P.; Antonio González, J.; Esparza-Rivera, J. R. Revista Mexicana de Ciencias Agrícolas. 2015, 6, 815825.

50. Kuti, J. O.; Konuru, H. B. J. Agric. Food Chem. 2004, 52, 117-121. DOI: https://doi.org/10.1021/jf030246y 